\title{
PENERAPAN METODE PEMBELAJARAN TUTOR SEBAYA (PEER LEARNING) BERBANTUAN MEDIA SCRAMBLE UNTUK MENINGKATKAN PENGUASAAN HURUF KATAKANA SISWA KELAS X IBB3 SMA NEGERI 3 SINGARAJA TAHUN AJARAN 2018/2019
}

\author{
L. Mahfiyana ${ }^{1}$ D.M.S. Mardani ${ }^{2}$ G.S. Hermawan ${ }^{3}$ \\ 123 Jurusan Pendidikan Bahasa Jepang, Universitas Pendidikan Ganesha, Singaraja,Bali \\ e-mail: layyin.mahfiyana@undiksha.ac.id \\ desak.mardani@undiksha.ac.id satya.hermawan@undiksha.ac.id
}

\begin{abstract}
Abstrak
Penelitian ini bertujuan untuk (1) mengetahui peningkatan penguasaan huruf katakana siswa dengan penerapan metode pembelajaran tutor sebaya (peer learning) berbantuan media scramble (2) mendeskripsikan respon siswa terhadap penerapan metode pembelajaran tutor sebaya (peer learning) berbantuan media scramble dalam mata pelajaran bahasa Jepang. Subjek penelitian ini adalah siswa kelas XIBB3 SMA Negeri 3 Singaraja tahun ajaran 2018/2019 yang berjumlah 35 orang. Metode pengumpulan data menggunakan observasi, angket dan tes. Data yang diperoleh dianalisis dengan menggunakan teknik deskriptif kuantitatif dan kualitatif. Hasil penelitian menunjukkan adanya peningkatan pada penguasaan huruf katakana siswa. Pada hasil pre-test persentase ketuntasan siswa adalah $14,28 \%$. Pada siklus I meningkat menjadi $71,42 \%$. Pada siklus II meningkat menjadi $100 \%$. Respon siswa terhadap penerapan metode pembelajaran tutor sebaya (peer learning) berbantuan media scramble tergolong sangat positif. Pada siklus I rata-rata respon siswa adalah 31,17 . Pada siklus II meningkat menjadi 33,05. Berdasarkan hasil penelitian tersebut disimpulkan bahwa penerapan metode pembelajaran tutor sebaya (peer learning) berbantuan media scramble dapat meningkatkan penguasaan huruf katakana.

Kata Kunci : Metode tutor sebaya, scramble, huruf katakana.
\end{abstract}

\section{要旨}

本研究は、1）片仮名の書く能力を向上するためのスクランブルによるpeer learning学習方法の実 施、2）片仮名の書く能力を向上寸るためのスクランブルによる peer learning学習方法の実施に対して の学習者の反応を明らかにすることを目的としている。研究の対象は2018/2019年度第三シンガラジ ヤ国立高等学校言語クラスの一年生の35名である。観察、アンケート、及びテストによる収集したデ 一タを定量的および定性的な記述法により分析した。その結果、片仮名の書く能力が向上したことが 分かった。事前テストの合格率が $14.28 \%$ 、一回目のサイクルの合格率が $71.42 \%$ 、二回目のサイクルの 合格率が100\%に達した。さらに、スクランブルによるpeer learning学習方法の実施に対して、学習者 はポジティブな反応をした。一回目のサイクルの平均点が 31.17 点であり、二回目のサイクルの平均 点が33.05点である。つまり、スクランブルによる peer learning学習方法の実施は、片仮名の書く能力 を向上できたと言えよう。

キーワード : peer learning、スクランブル、片仮名 


\section{Pendahuluan}

Dalam mempelajari bahasa Jepang, huruf merupakan salah satu hal mendasar yang harus dipelajari dan dikuasai. Huruf Jepang tersebut dibagi menjadi tiga jenis huruf yang berbeda yaitu huruf hiragana, katakana dan kanji. Huruf Jepang yang pertama diajarkan adalah huruf hiragana yang berjumlah 46 huruf. Setelah pembelajaran huruf hiragana selesai, selanjutnya diajarkan huruf katakana dengan jumlah yang sama yaitu 46 huruf. Sebagai pembelajar bahasa Jepang, huruf katakana sangatlah penting untuk dikuasai. Namun, mempelajari huruf Jepang seperti huruf katakana tentu bukan hal yang mudah. Dengan jumlah yang lebih banyak dan bentuk huruf yang berbeda dari huruf alphabet, menguasai huruf Jepang menjadi kesulitan tersendiri bagi pelajar bahasa Jepang, salah satunya terjadi di kelas XIBB3 SMA Negeri 3 Singaraja. Siswa merasa kesulitan dalam menguasai huruf katakana dibandingkan huruf hiragana. Hal ini dapat dibuktikan dari hasil wawancara dengan guru, observasi, pre-test dan ditemukan bahwa sebagian besar siswa tidak dapat menguasai huruf katakana.

Berdasarkan hasil wawancara dengan guru pengampu mata pelajaran bahasa Jepang, observasi dan analsisis pre-test dapat dipastikan bahwa permasalahan mengenai rendahnya penguasaan huruf katakana terjadi di kelas XIBB3. Permasalahan tersebut terjadi karena yang pertama siswa kurang mampu memahami perbedaan huruf katakana yang memiliki kemiripan bentuk seperti huruf ツ(tsu) denganシ(shi), ソ(so) denganン(n) dan ル(ru) dengan $レ(r e)$, yang kedua siswa kurang memahami lambang bunyi chokuon seperti huruf ベ (be), danペ(pe) pada huruf katakana, yang ke tiga adalah siswa kurang berlatih dalam membaca dan menulis huruf katakana.

Berdasarkan hasil analisis pre-test dapat diketahui sebanyak $77,14 \%$ siswa mengalami kesalahan pada huruf ツ(tsu) dan シ(shi). Sebanyak 85,71\% siswa mengalami kesalahan pada huruf ソ (so) dan ン(n). Sebanyak 42,85\% siswa mengalami kesalahan pada huruf $54,28 \%$ siswa mengalami kesalahan pada huruf ク (ku) danケ(ke). Sebanyak 62,85\% mengalami kesalahan pada huruf ベ(be), siswa menjawab cara baca pe pada huruf ベ(be).

Untuk mengatasi permasalahan tersebut, maka diperlukan adanya suatu perbaikan pada metode pembelajaran maupun media pembelajaran yang digunakan. Salah satu metode pembelajaran yang dapat digunakan adalah metode pembelajaran tutor sebaya (peer learning) berbantuan media scramble. Penggunaan metode dan media pembelajaran ini juga disesuaikan dengan karakteristik serta kebutuhan siswa kelas X IBB 3. Siswa cenderung kurang fokus, kurang aktif, malu untuk menanyakan materi yang belum dipahami kepada guru sehingga siswa memecahkan kesulitan belajarnya kepada 5 orang siswa lainnya yang memiliki kemampuan lebih tinggi terkait huruf katakana. Kebutuhan siswa kelas X IBB 3 adalah latihan huruf katakana yang menyenangkan agar siswa dapat lebih mudah dalam mengingat maupun menguasai huruf katakana.

Menurut McGoey,dkk (dalam Abaoud, 2016) metode pengajaran tutor sebaya dilakukan dengan siswa yang bekerja sama dalam kelompok untuk kegiatan akademik, satu siswa memberikan bantuan, intstruksi dan umpan balik pada siswa lainnya.

Metode pembelajaran tutor sebaya merupakan sumber belajar selain guru, yaitu teman sebaya yang lebih pandai memberikan bantuan belajar kepada teman-teman sekelasnya di sekolah. Belajar dengan teman sebaya dapat menghilangkan kecanggungan oleh siswa yang takut untuk bertanya kepada guru serta dapat menambah penguasaan bagi siswa yang menjadi tutor dan anggota di dalam kelompok belajar. Dengan menerapkan metode tutor sebaya, siswa dapat lebih leluasa dan aktif belajar bersama dengan temannya. Hal ini didukung oleh pernyataan dari Lie (2004:30) yang menyatakan bahwa pengajaran oleh rekan sebaya (tutor sebaya) ternyata lebih efektif dari pengajaran oleh guru, karena disebabkan oleh latar belakang, pengalaman para siswa yang mirip satu dengan lainnya dibandingkan dengan skemata guru. Hal ini sesuai dengan karakteristik siswa kelas X IBB 3 yaitu malu atau canggung untuk menanyakan materi yang belum dipahami kepada guru dan cenderung memecahkan kesulitan belajarnya kepada teman sebaya yang memiliki kemampuan lebih tinggi. Selain penggunaan metode tutor sebaya, dibantu dengan penggunaan media scramble yang sesuai dengan kebutuhan siswa kelas X IBB 3. 
Media scramble merupakan pendukung dari metode pembelajaran tutor sebaya. Media scramble dapat dijadikan latihan oleh siswa agar dapat menguasai materi yang diberikan dengan cara yang menyenangkan sehingga siswa tidak bosan dalam proses pembelajaran. Hal ini didukung oleh pernyataan dari Suparno (dalam Amanah, 2011) yang menyatakan bahwa scramble merupakan salah satu permainan bahasa, pada hakikatnya permainan bahasa merupakan suatu aktifitas untuk memperoleh keterampilan tertentu dengan cara yang menggembirakan. Sehingga, dengan penggunaan media scramble, siswa dapat berlatih huruf-huruf katakana dengan cara yang menyenangkan.

Penelitian mengenai penggunaan metode tutor sebaya (peer learning) sudah pernah dilakukan sebelumnya oleh Danasasmita (2016). Dalam penelitian Danasasmita, didapatkan bahwa penggunaanmetode tutor sebaya (peer learning) dapat meningkatkan penguasaan huruf hiragana dari hasil rata-rata pre-test sebesar 44,14 dalam kategori kurang sebelum diterapkannya metode tutor sebaya (peer learning). Setelah dilaksanakan penelitian, dengan menerapkan metode tutor sebaya (peer learning) diperoleh hasil rata-rata post-test sebesar 95,86 dengan kategori sangat baik. Penelitian mengenai penerapan scramble juga pernah dilakukan oleh Saputra (2015) yang menunjukkan bahwa media scramble dapat membantu meningkatkan penguasaan kosakata bahasa Jepang siswa.

Berdasarkan latar belakang tersebut, dapat dirumuskan rumusan masalah sebagai berikut. 1) Apakah penerapan metode pembelajaran tutor sebaya (peer learning) berbantuan media scramble dapat meningkatkan kemampuan penguasaan huruf katakana siswa kelas $\mathrm{X}$ IBB 3 di SMAN 3 Singaraja tahun ajaran 2018/2019?. 2) Bagaimanakah respons siswa terhadap penggunaan metode pembelajaran tutor sebaya (peer learning) berbantuan media scramble untuk meningkatkan kemampuan penguasaan huruf katakana siswa kelas X IBB 3 di SMAN 3 Singaraja tahun ajaran 2018/2019?

\section{Metode}

Penelitian tindakan kelas ini dilakukan di SMA Negeri 3 Singaraja pada semester II tahun ajaran 2018/2019. Subjek yang digunakan adalah siswa kelas X IBB 3 dengan jumlah keseluruhan 35 orang siswa. Objek dalam penelitian ini adalah penguasaan huruf katakana.

Penelitian ini direncanakan dilaksanakan dengan 2 siklus. Namun, apabila belum memenuhi target penelitian, maka dilanjutkan dengan siklus selanjutnya. Pada setiap siklus dilakukan dengan 4 tahap yaitu perencanaan, pelaksanaan tindakan, observasi dan refleksi. Berikut adalah bagan siklus penelitian yang digunakan dalam penelitian ini

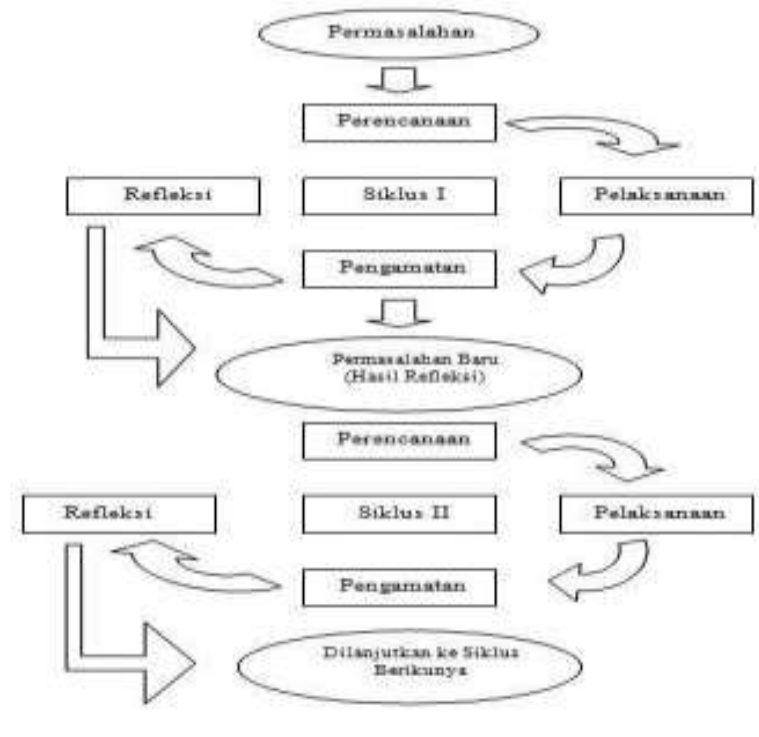

Gambar 1

Siklus PTK (Sumber; Rubiyanto dkk., 2008: 120) 
Metode pengumpulan data yang digunakan adalah metode observasi, kuesioner dan tes. Data hasil observasi di analisis menggunakan deskriptif kualitatif dan kuantitaif. Adapun rumus yang digunakan untuk analisis data hasil belajar siswa adalah sebagai berikut.

Ketuntasan Individu

Keterangan:

$$
N A=\frac{S P}{S M I} \times 100
$$

NA : Nilai Akhir / nilai tes yang diperoleh

SP : Skor Perolehan / jumlah huruf yang di jawab benar

SMI : Skor Maksimal Ideal / jumlah huruf seluruhnya

$$
\begin{gathered}
\text { Ketuntasan Klasikal } \\
\text { Ketuntasan klasik }=\frac{\sum \text { siswa yang memperoleh nilai } \geq 80}{\sum \text { seluruh siswa }} \times 100
\end{gathered}
$$

Sedangkan analisis data untuk kuesioner menggunakan rumus sebagai berikut.

Keterangan

$$
\mathrm{P}=\frac{f}{N} \times 100 \%
$$

$P \quad=$ persentase jawaban

$\mathrm{f} \quad=$ frekuensi setiap jawaban dari responden

$\mathrm{N} \quad=$ jumlah responden

$100 \%=$ persentase frekuensi dari tiap jawaban responden.

Untuk menghitung skor rata-rata respons siswa secara klaksikal digunakan rumus sebagai berikut.

$$
\mathrm{X}=\frac{\sum \mathrm{n}}{\mathrm{n}}
$$

Keterangan

$$
\text { (Nurkancana dan Sunartana, 1992) }
$$

$X$ : Skor rata-rata respons siswa

$\sum \mathrm{n}$ : Jumlah skor respon seluruh siswa

$\mathrm{n}$ : Jumlah siswa

Sedangkan untuk menggolongkan respon siswa termasuk dalam kriteria bagaimana, berikut merupakan interval yang menunjukkan kriteria respon siswa.

Tabel 1

Penggolongan Respons Siswa

\begin{tabular}{|c|c|}
\hline Skor & Kriteria \\
\hline$\overline{\mathrm{X}} \geq 33$ & Sangat Positif \\
\hline $26 \leq \overline{\mathrm{X}}<33$ & Positif \\
\hline $19 \leq \overline{\mathrm{X}}<26$ & Cukup Positif \\
\hline $12 \leq \overline{\mathrm{X}}<19$ & Kurang Positif \\
\hline$\overline{\mathrm{X}}<12$ & $\begin{array}{c}\text { Sangat Tidak } \\
\text { Positif }\end{array}$ \\
\hline
\end{tabular}

\section{Hasil dan Pembahasan}

Sebelum dilaksanakannya tindakan, terlebih dahulu dilakukan observasi dan pemberian pre-test kepada siswa kelas X IBB 3 untuk mengetahui kondisi awal siswa kelas tersebut. Berdasarkan hasil observasi awal yang dilakukan pada tanggal 17 September 2018, permasalahan huruf katakana siswa kelas XIBB3 adalah kurangnya kemampuan membaca, menulis dan membedakan huruf katakana yang memiliki kemiripan bentuk. Saat guru meminta 
siswa untuk membaca kosakata dalam huruf katakana seperti バドミントン (badominton), siswa merasa kesulitan dalam membacanya, sehingga siswa membaca kosakata tersebut menjadi badomisotoso. Disamping kurangnya kemampuan membaca huruf katakana, siswa juga kesulitan dalam menulis huruf katakana. Siswa kurang mampu menulis huruf katakana dari kosakata roomaji dengan baik dan benar. Setelah dilaksanakannya observasi awal, dilanjutkan dengan pemberian pre-test.Pre-test diberikan dengan bertujuan untuk mengetahui sejauh mana penguasaan huruf katakana siswa. Hasil analisis pre-test menunjukkan bahwa sebagian besar siswa memperoleh nilai dibawah KKM. Hanya ada 5 orang siswa yang memenuhi nilai diatas KKM dan 30 orang siswa belum memenuhi KKM dengan nilai dibawah 75. Rata-rata yang dihasilkan yakni 54,4 dengan persentase ketuntasan mencapai $14,28 \%$ dan persentase siswa tidak tuntas mencapai $85,71 \%$. Dari hasil analisis pre-test menunjukkan bahwa siswa masih kesulitan dalam membaca, menulis, mengingat dan membedakan hurufhuruf katakana yang memiliki kemiripan bentuk seperti ツ(tsu), シ(shi), ソ(so), ン(n), ル(ru), レ (re), ク(ku) danケ(ke) serta bingung dalam lambang bunyi chokuon seperti huruf ベ(be), dan ヘํ(pe).

Berdasarkanpermasalahan tersebut maka dilakukan tindakan berupa Penelitian Tindakan Kelas (PTK) dengan menerapkan metode pembelajaran tutor sebaya (peer learning) berbantuan media scramble untuk meningkatkan penguasaan huruf katakana siswa kelas $\mathrm{X}$ IBB 3 SMA Negeri 3 Singaraja. Penelitian ini dilaksanakan dalam dua siklus. Masing-masing siklus terdiri dari 3 kali pertemuan. Pertemuan pertama siklus I dilaksanakan pada tanggal 25 Maret 2015 dengan alokasi waktu 3x45 menit (08.00-10.15). Hasil observasi pertemuan pertama menunjukkan bahwa siswa masih beradaptasi terhadap penggunaan metode tutor sebaya berbantuan media scramble. Siswa juga tampak kurang antusias dalam mengikuti pembelajaran. Pertemuan kedua siklus I dilaksanakan pada tanggal 15 April 2019. Hasil observasi menunjukkan bahwa adanya peningkatan dalam proses pembelajaran. Siswa sudah memperlihatkan antusiasme dalam belajar dengan memperhatikan penjelasan guru di depan kelas, melaksanakan pembelajaran menggunakan metode tutor sebaya dengan cukup baik. Serta pada akhir pembelajaran, siswa aktif dalam merangkum materi pembelajaran.

Pada tanggal 22 April 2019, dilaksanakan pemberian post-test siklus I untuk mengukur kemampuan siswa terkait penguasaan huruf katakana yang sudah dipelajari sebbelumnya. Hasil analisis post-test menunjukkan adanya peningkatan dari hasil tes awal. Pada post-test siklus I terdapat 25 orang siswa memperoleh nilai tuntas diatas nilai KKM yaitu 75. Sedangkan 10 orang lainnya belum mencapai nilai KKM. Rata-rata yang diperoleh sebesar 77,48 dengan persentase ketuntasan $71,42 \%$. Hasil post-test I disajikan dalam bentuk gambar sebagai berikut.

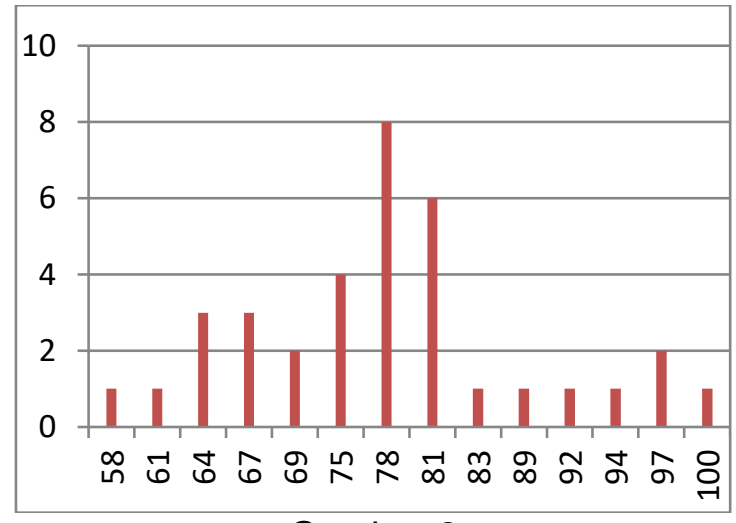

Gambar 2

Diagram Hasil Post-test I

Untuk mengetahui peningkatan ketuntasan yang dialami dari hasil pre-test dengan post-test I, perbandingan nilai siswa disajikan dalam bentuk gambar sebagai berikut. 


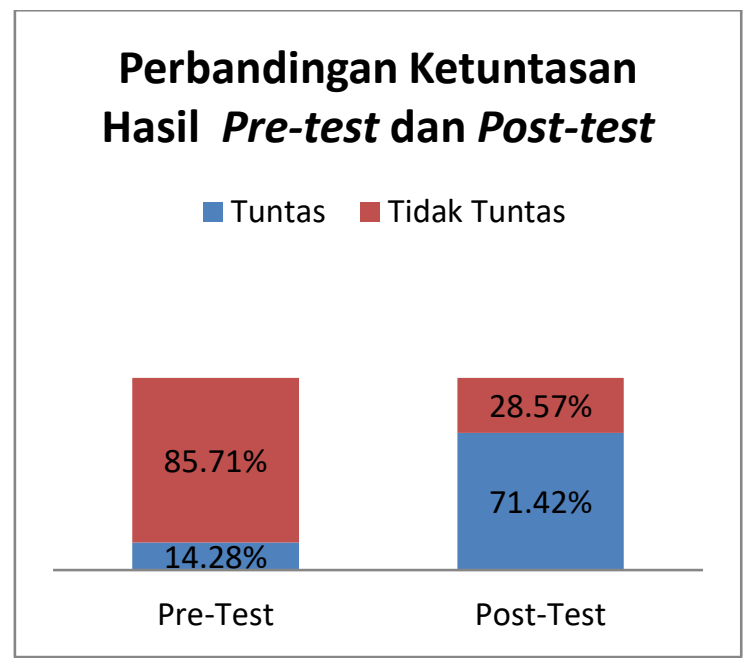

Gambar 3

Perbandingan Ketuntasan Hasil Pre-test dan Post-test Siklus I

Berdasarkan diagram tersebut, dapat diketahui terjadi peningkatan ketuntasan hasil belajar dari sebelum dan sesudah diterapkannya metode tutor sebaya berbantuan media scramble dalam meningkatkan huruf katakana.

Selain dilaksanakan post-test I, siswa juga diberikan kuesioner guna untuk mengetahui respon siswa terhadap penggunaan metode tutor sebaya berbantuan media scramble. Pada kuesioner tertutup, respon siswa mengenai penerapan metode tutor sebaya (peer learning) berbantuan media scramble cukup beragam. Di setiap point uraian, respon positif dari siswa lebih banyak dibandingkan dengan respon negatif. Pada hasil analisis kuesioner tertutup, diperoleh rata-rata siklus I sebesar 31,17 dan tergolong positif. Sedangkan pada analisis kuesioner terbuka menyatakan bahwa siswa dapat berdiskusi dan bekerja sama dengan kelompok, dapat belajar dan berlatih huruf katakana dengan suasana yang menyenangkan serta membantu siswa dalam membaca dan menulis huruf katakana.

Setelah dilaksanakannya siklus I, dilanjutkan dengan pelaksanaan siklus II. Pelaksanaan siklus II berpedoman pada refleki siklus I dengan melakukan perbaikan terhadap kendala yang dialami pada siklus I yaitu1) Saat pelaksanaan metode pembelajaran tutor sebaya berbantuan media scramble diberikan penjelasan, bimbingan maupun arahan terkait langkah-langkah penerapan metode tutor sebaya dengan media scramble sehingga siswa dapat lebih memahami dalam penggunaan metode tutor sebaya dan media scramble. 2) Pada pengelolaan kelas terutama ketika pembelajaran berkelompok, dilakukan pembagian kelompok dengan mengatur letak masing-masing kelompok sehingga siswa dapat membentuk kelompok sesuai dengan yanng diarahkan. Hal ini dapat meminimalisir keributan siswa saat menentukan letak kelompok bersama temannya. 3) Pada pelaksanaan media scramble, dilakukan pengaturan waktu agar tidak terlalu cepat agar siswa memiliki banyak waktu untuk merangkai huruf katakana menjadi kosakata. Sehingga, siswa dapat mencari dan membaca dengan teliti terkait potongan kartu huruf-huruf katakana. 4) Ketika siswa menulis huruf katakana yang di instruksikan di depan kelas, siswa diberikan motivasi agar lebih percaya diri dan tidak takut salah dalam menjawab serta diberikan reward berupa pujian agar siswa lebih termotivasi. 5) Huruf-huruf yang menjadi kendala pada siklus I diulang kembali pada siklus II dan dijadikan latihan, ditekankan perbedaannya, dijelaskan bagaimana penulisannya serta diujikan kembali pada post-test II.

Pertemuan pertama pada siklus II dilaksanakan pada tanggal 29 April 2019. Hasil observasi menunjukkan bahwa siswa sudah mampu beradaptasi dengan baik terhadap penggunaan metode tutor sebaya dan media scramble, siswa dapat belajar secara aktif bersama temannya dalam kelompok dan meningkatnya rasa percaya diri siswa saat mengerjakan soal yang diberikan. Sedangkan pada pertemuan kedua siklus II dilaksanakan pada tanggal 6 Mei 2019. Hasil observasi menunjukkan bahwa proses pembelajaran dengan penerapan metode pembelajaran tutor sebaya berbantuan media scramble dapat berjalan 
dengan baik. Dari awal pembelajaran sampai akhir pembelajaran siswa memperlihatkan antusiasme dalam belajar dengan belajar bersama teman sebaya di dalam kelompok. Siswa memperhatikan penjelasan guru dengan baik, merespon pertanyaan dari guru, percaya diri dalam mengerjakan soal yang diberikan serta aktif dalam kegiatan pembelajaran.

Pemberian post-test II dilaksanakan pada tanggal 13 Mei 2019. Hasil post-test II menunjukkan adanya peningkatan hasil belajar yang signifikan yaitu seluruh siswa memperoleh nilai tuntas dengan nilai diatas KKM. Nilai tertinggi yang diperoleh adalah 100 , sedangkan nilai terendah yang diperoleh adalah 77 . Berikut adalah hasil post-test II yang disajikan dalam bentuk gambar sebagai berikut.

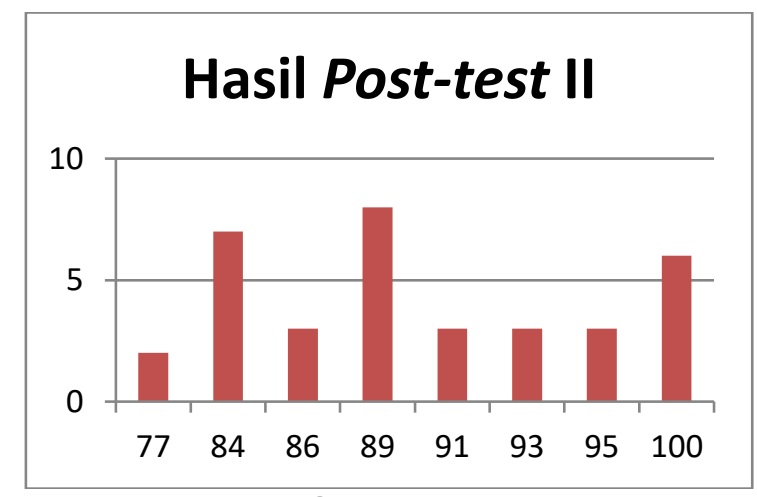

\section{Gambar 4 \\ Hasil Post-test II}

Nilai rata-rata yang diperoleh siswa sebesar 90,22 dengan ketuntasan klasikal mencapai $100 \%$. Untuk mengetahui peningkatan ketuntasan yang dialami dari hasil pre-test, post-test I dan post-test II, perbandingan nilai siswa disajikan dalam bentuk gambar sebagai berikut.

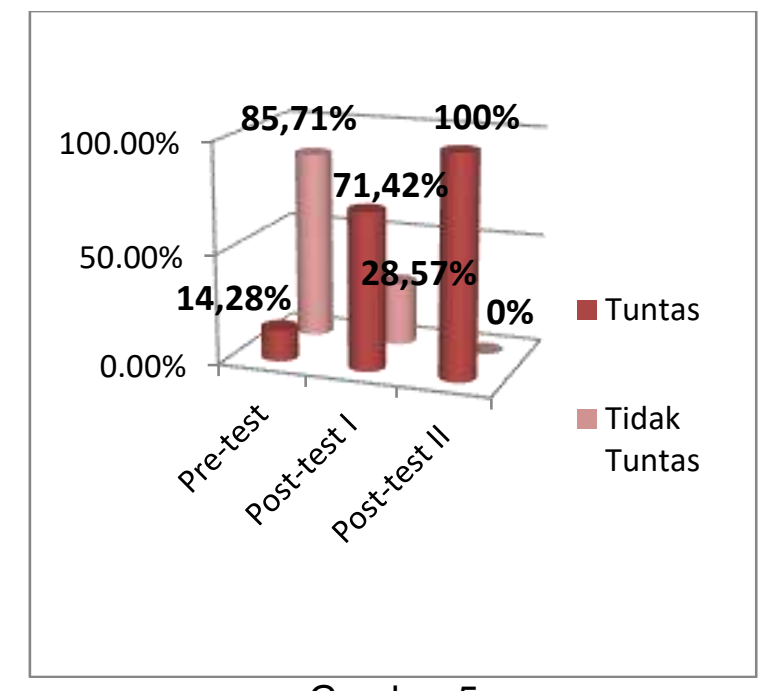

Gambar 5

Perbandingan Ketuntasan Hasil Pre-test, Post-test I dan Post-test II

Berdasarkan gambar 5, dapat diketahui terjadi peningkatan yang signifikan dari hasil pre-test, post-test I dan post-test II sebelum dan sesudah diterapkannya metode pembelajaran tutor sebaya berbantuan media scramble. Ketercapaian hasil belajar pada penelitian ini sesuai dengan hasil penelitian yang dilakukan oleh Danasasmita (2016) yang menyatakan bahwa penerapan metode tutor sebaya mampu meningkatkan hasil belajar siswa dengan memperoleh ketuntasan belajar dan rata-rata yang meningkat. Walaupun subjek dan jenis 
penelitian tersebut berbeda tetapi memiliki tujuan yang sama yaitu ingin meningkatkan hasil belajar siswa.

Berdasarkan hasil kuesioner siklus II. Rata-rata yang diperoleh juga meningkat menjadi 33,05 yang tergolong sangat positif. Sedangkan pada kuesioner terbuka diperoleh jawaban yang beragam, diantaranya adalah membantu siswa meningkatkan kemampuan membaca dan menulis huruf katakana, lebih mudah mengingat huruf katakana dan membaca kosakata huruf katakana, dapat membedakan huruf-huruf katakana yang memiliki kemiripan bentuk dan mengetahui perbedaannya dari cara penulisan dan urutannya serta dapat berlatih dan belajar dengan suasana pembelajaran yang menyenangkan.

Hasil refleksi siklus II menunjukkan bahwa peningkatan yang terjadi pada siklus II disebabkan oleh proses pembelajaran yang sesuai dengan prosedur perencanaan pembelajaran yang telah dirumuskan, pengelolaan kelas yang baik, penerapan langkahlangkah metode pembelajaran tutor sebaya (peer learning) dan media scramble yang telah sesuai, manajemen waktu yang baik dalam proses pembelajaran serta melakukan perbaikan terhadap kendala-kendala yang terjadi pada siklus I. Perbaikan pada siklus II telah menunjukkan hasil yang maksimal dan seluruh siswa telah memenuhi kriteria keberhasilan yang ditetapkan, yakni ketuntasan individu dan ketuntasan klasikal. Pada ketuntasan individu, siswa telah memenuhi nilai KKM yaitu 75. Sedangkan pada ketuntasan klasikal telah memenuhi ketuntasan sebesar $75 \%$.

Dilihat dari hasil pelaksanaan siklus I dan siklus II, secara garis besr perolehan hasil belajar seluruh siswa kelas X IBB 3 SMA Negeri 3 Singaraja meningkat, bahkan pada hasil belajar siklus II seluruh siswa telah memperoleh nilai diatas KKM dengan ketuntasan $100 \%$. Selain peningkatan hasil belajar, diperoleh juga hasil kuesioner yang menunjukkan respon sangat positif sehingga tidak ditemukan masalah lagi pada siklus II. Hasil penelitian siklus II merupakan tindakan terbaik karena dapat meningkatkan hasil belajar maupun respon siswa dalam pembelajaran huruf katakana.

Dari pemaparan tersebut dapat disimpulkan bahwa penggunaan metode tutor sebaya (peer learning) berbantuan media scramble mampu meningkatkan penguasaan huruf katakana siswa kelas X IBB 3 SMA Negeri 3 Singaraja tahun ajaran 2018/2019.

\section{Simpulan dan Saran}

Berdasarkan analisis hasil dan pembahasan terhadap penelitian tindakan kelas (PTK) pada kelas X IBB 3 dengan diterapkannya metode pembelajaran tutor sebaya (peer learning) berbantuan media scramble untuk meningkatkan penguasaan huruf katakana, dapat ditarik kesimpulan sebagai berikut. 1) Berdasarkan hasil analisis data tes diperoleh nilai rata-rata pretest 54,4 dengan nilai ketuntasan klasikal mencapai $14,28 \%$. Setelah diterapkannya metode pembelajaran tutor sebaya berbantuan media scramble diperoleh nilai rata-rata post-test I menjadi 77,48 dengan persentase ketuntasan sebesar $71,42 \%$. Pada post-test II terjadi peningkatan nilai rata-rata menjadi 90,22 dan persentase ketuntasan siswa sebesar $100 \%$. 2) Berdasarkan hasil analisis data kuesioner, diperoleh respon siswa mengenai penerapan metode pembelajaran tutor sebaya berbantuan media scramble tergolong dalam kategori sangat positif. Pada hasil analisis angket tertutup, diperoleh rata-rata siklus I adalah 31,17 dan siklus II meningkat menjadi 33,05. Pada hasil analisis angket terbuka menyatakan bahwa siswa dapat lebih mudah dalam membaca, menulis, mengingat, membedakan huruf katakana yang memiliki kemiripan bentuk, menggunakan huruf katakana serta lebih termotivasi dalam mengikuti pembelajaran.

Sebagai bentuk tindak lanjut dari penelitian ini, terdapat beberapa saran yang ditujukan kepada pihak-pihak terkait sebagai berikut.

\section{Bagi Pengajar}

Metode tutor sebaya berbantuan media scramble diharapkan dapat dijadikan salat satu metode yang dapat digunakan oleh pengajar yang disesuaikan dengan karakteristik siswa guna untuk meningkatkan prestasi siswa dan menciptakan suasana pembelajaran lebih menyenangkan serta memotivasi siswa untuk terlibat aktif dalam kegiatan pembelajaran. 
2. Bagi Peneliti Lainnya

Hasil penelitian ini diharapkan dapat dijadikan acuan untuk peneliti lainnya yang ingin melakukan penelitian tindakan kelas pada permasalahan yang berbeda atau mata pelajaran lainnya dengan tetap memperhatikan hambatan-hambatan yang terjadi pada penelitian ini sehingga hambatan yang dialami tidak terulang kembali dan dapat disempurnakan. Bagi peneliti lainnya dalam menggunakan media scramble, diharapkan tidak terpaku dalam penguasaan huruf saja namun, dapat juga digunakan untuk meningkatkan penguasaan kosakata dengan memodifikasi media sesuai dengan penguasaan mata pelajaran yang ingin ditingkatkan. Sehingga, media scramble ini tidak khusus digunakan dalam penelitian kemampuan penguasaan huruf katakana, tetapi dapat juga diterapkan pada keterampilan berbahasa lainnya.

\section{Daftar Pustaka}

Abaoud,A.Abdurahman. "Implementation Of Peer Tutoring Strategies In Teaching Students With ADHD:Teahers' Attitudes In Saudi Education”. Journal od educatoin and practice, Vol 7, No 30, 2016. Tersedia Pada https://pdfs.semanticscholar.org (19 Februari2019).

Amanah, Siti. 2011. "Pembelajaran Kooperatif Metode Scramble" tersedia pada http://www.aresearch.upi.edu.com (10 November 2018).

Danasasmita, Rasiban\&Soleha. 2016. "Pengaruh Penggunaan Metode Peer Learning Terhadap Penguasaan Penggunaan Huruf Hiragana (Penelitian Eksperimen Semu Terhadap Siswa Kelas 7 Smp Laboratorium Percontohan UPI Tahun Ajaran 2014/2015)". Jurusan Pendidikan Bahasa Jepang, Universitas Pendidikan Indonesia, Jurnal Japanedu, Vol 1, No 1, Juni 2016. Tersedia pada ejournal.upi.edu (5 November 2018).

Lie, Anita. Cooperative Learning. Jakarta:Grasindo

Rubiyanto, Rubino dan Saring Marsudi. 2008. Penelitian Tindakan Kelas KeSDan dan Karya Tulis IImiah. Surakarta:Fairuz Media

Saputra, I Kadek Paneda, dkk. 2015. Penerapan Metode Scramble Untuk Meningkatkan Penguasaan Kosakata Bahasa Jepang Pada Siswa Kelas XI IPA SMA Karya Wisata Singaraja Tahun Ajaran 2014/2015. Jurnal Pendidikan Bahasa Jepang Undiksha, Vol.3 No.1 Edisi 2015. Singaraja: Undiksha. Tersedia Pada https://ejournal.undiksha.ac.id/indeks.php//JJPBJ/article/view/5436

(13 Juni 2019). 